\title{
Equilibrium Analysis on Total Supply and Demand for Urban Commercial Housing in China
}

\author{
Mengke Zhang \\ Shanghai University, 99 Shangda Road, BaoShan District, Shanghai, China \\ zmk_shu@163.com
}

Keywords: Urban commercial housing; Supply and demand; Equilibrium

\begin{abstract}
This paper analyzes the current situation of supply and demand imbalance of urban commercial housing market between 1998 and 2016 in China from the perspective of sold area and floor area completed. Then it constructs VAR model and predicts the supply and demand for urban commercial housing from 2017 to 2020 . Finally, we can make conclusion that whether the growth rate is optimistic, neutral or pessimistic, China's urban housing market will be in short supply in the next four years, and its imbalance phenomenon will more obvious in 2020.
\end{abstract}

\section{Introduction}

In 1998, the welfare housing system is abolished; and housing market has fully completed the change of monetization and commercialization of housing distribution, which promotes the housing industry to become a new economic growth point in China. Since the housing reform, housing market has risen in sales and price, and there has been an imbalance in the amount and price. We regard completed floor area as housing supply and find that housing market has remained tight after 2004. The gap between supply and demand has certain periodicity. Meanwhile, sold price of commercial housing has increased rapidly. The average annual growth rate of housing price is about $7.83 \%$ since 1998. And government has come up with policies about the regulation and control on land and finance in order to keep housing market steady. Consequently, it is worth paying attention to the equilibrium on total supply and demand for urban commercial housing in China.

\section{Literature Review}

Factors Affecting both Housing Supply and Demand. Many scholars have done a lot of researches about the impact of housing prices on housing demand and/or supply (J.M. Wang and T.M. Gao, 2004 [1]; Z.Z. Zou and L.L. Niu, 2010 [2]; T. Yan, 2013 [3]). They think housing price is an important factor affecting the supply and demand for housing. C. Zhang (2015) believes that economy is an important foundation to support the development of the real estate market [4].

Factors Affecting the Housing Supply. G.H. Cao (2002) uses the correlation coefficient analysis and makes a conclusion that urban population is the key factor affecting the total amount of housing demand [5]. Z.Y. Ding (2014) concludes that in the early urbanization, large numbers of people gather in the city, which leads to house prices rising and more houses are provided [6]. D. Dipasquale and W.C. Wheaton (1996) [7], D.Q. Jiang (2001) [8], H.Y. Liu and R.R. Ren (2007) [9] and X.L. Tao (2012) [10] have confirmed the impact of income on housing demand. The increase of disposable income represents the improvement of residents' purchasing power. In addition to population and income, there are other factors that affect housing demand, such as resettlement, society and culture.

Factors Affecting the Housing Demand. Land is an important component of housing costs. H.M. Zhang (1998) believes that land is a major factor affecting housing supply, and there is a mutual promotion between land supply and housing prices [11]. Except the price of land, the amount of capital input and the price of labor and materials are also the main factors affecting housing supply. D.J. McKcnzic and R.M. Betts (2009) think that housing supply is dominated by the existing housing [12]. 


\section{Analysis on the Supply and Demand for Urban Commercial Housing in China}

Demand for Urban Commercial Housing. We can measure total demand for urban commercial housing of China with sold area. As is shown in figure 1, we can see that since 1998, there is an increasing demand for urban housing market, in addition to 2008 and 2014. In 2016, sales area of commercial housing has an increase of $22.35 \%$ over 2015 with $1,375.4$ million sq.m; and the average sold price is 7,205 yuan/sq.m, up $11.31 \%$ over 2015 .

Supply for Urban Commercial Housing. We can measure overall supply for urban commercial housing in China from two aspects, which are floor area completed of urban commercial housing and completion of residence investment. As is vividly indicated in the figure 1 below, the floor area completed has showed an upward trend, but the growth rate declines year by year. In 2015, compared with 2014, the area decreases by $8.77 \%$, and in 2016 , there is an increase of $4.62 \%$ over the previous year. Meanwhile, the average annual growth rate of completed area $(9.89 \%)$ is less than that of the construction area (16.32\%), which leads to the downward trend of housing completion rate. A glance at the figure 2 provided depicts the completion of residence investment from real estate developers. In 2016, China has completed 6,870.4 billion yuan of residential investment, an increase of $6.36 \%$ over last year.

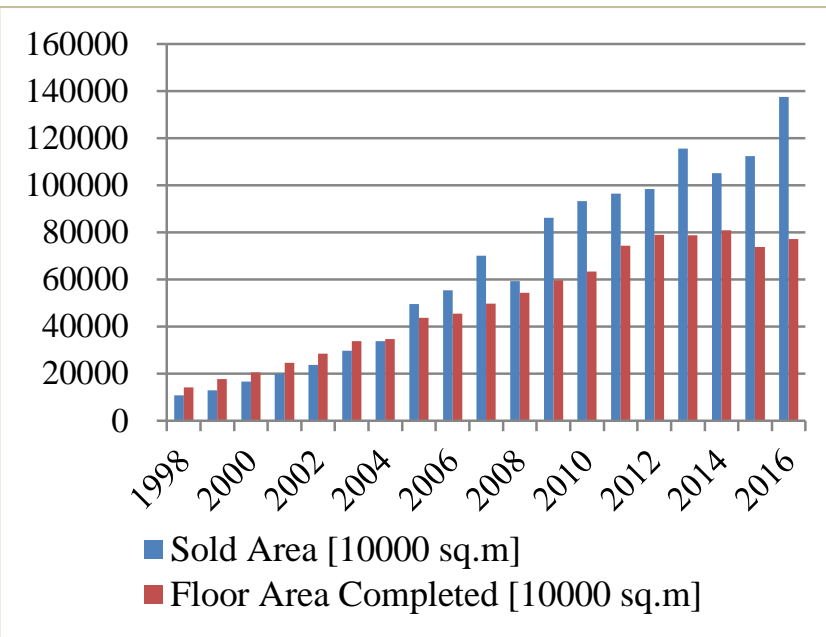

Fig. 1 Sold Area and Floor Area Completed of Commercial Housing in China (1998-2016)

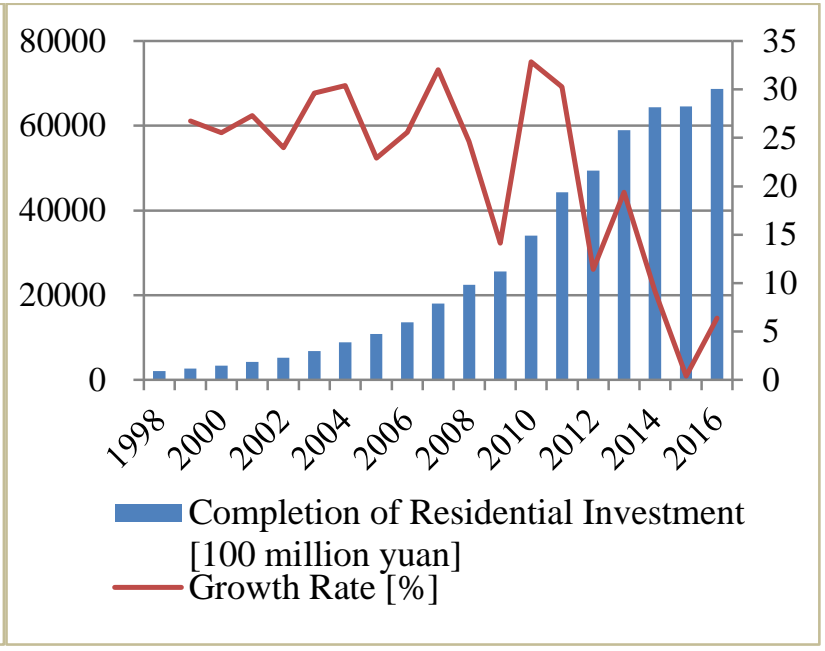

Fig. 2 Completion of Residential Investment in China (1998 -2016)

On the whole, from the supply point of view, real estate developers find that housing market is profitable, and then invest in commercial housing, whose decisions have been made irrationally. However, the salariat is the biggest force in the housing market, whose effective demand cannot be satisfied. From the perspective of demand, with the acceleration of urbanization, there has been a significant increase in the demand for urban commercial housing; however, low-income families are still the subjects of demand. If the market lacks effective housing supply, it will not stimulate public consumption. Furthermore, housing market is a seller's market, which remains higher commercial housing prices, so the public is often unable to buy them. There is a serious unbalanced state between commercial housing price and the actual purchasing power of urban residents. What's more, structural surplus makes higher inventory, so destocking has become the main line of commercial housing regulation policy. Although China's destocking has achieved initial success, lower-tier cities are still under inventory pressure.

\section{Demand Model of Urban Commercial Housing in China}

Based on the analysis of housing demand factors above and the availability of data, the following variables are selected to build the model of urban commercial housing demand in China. The data are derived from China Statistical Yearbook and National Bureau of Statistics of China website between 1998 and 2016. 
Table 1 Variables of Demand Model of Urban Commercial Housing in China

\begin{tabular}{cccc}
\hline Variable Categories & Variable Description & Variable Names [unit] & Abbreviation \\
\hline \multirow{2}{*}{ Explained variable } & $\begin{array}{c}\text { Urban commercial } \\
\text { housing demand index }\end{array}$ & $\begin{array}{c}\text { Sold Area of Commercial } \\
\text { Housing } \\
{[10000 \text { sq.m] }}\end{array}$ & QD \\
\hline & Urban commercial & Sold Price of Commercial & PT \\
Explang price index & Housing [yuan/sq.m] & Urban Population \\
& Urbanization index & [10000 persons] & UP \\
& Income level index & $\begin{array}{c}\text { Per Capita Disposable Income of } \\
\text { Urban Residents [yuan] }\end{array}$ & PCDI \\
\hline
\end{tabular}

In order to eliminate the influence of data dimension and the possible heteroscedasticity of time series, the above indexes are processed by logarithm. After logarithmic processing, they are defined as LN_QD, LN_PT, LN_UP and LN_PCDI. Then EViews7.2 is used to perform ADF test, co-integration test and Granger-causality test. Finally, the VAR model is constructed and the following equation is obtained:

LN_QD $=-0.8802 * \mathrm{D}\left(\mathrm{D}\left(\mathrm{LN} \_\mathrm{PCDI}(-1)\right)\right)+0.2726 * \mathrm{D}\left(\mathrm{D}\left(\mathrm{LN} \_\mathrm{PCDI}(-2)\right)\right)+1.3806 * \mathrm{D}\left(\mathrm{LN} \_\mathrm{PT}(-1)\right)+0$ $.6623 * \mathrm{D}\left(\mathrm{LN} \_\mathrm{PT}(-2)\right)-0.3848 * \mathrm{LN} \_\mathrm{QD}(-1)+1.1478 * \mathrm{LN}$ QD(-2)+2.0226*D(D(LN_UP(-1)))-13.639 $3 * \mathrm{D}\left(\mathrm{D}\left(\mathrm{LN} \_\mathrm{UP}(-2)\right)\right)+2.7034$

\section{Supply Model of Urban Commercial Housing in China}

Based on the analysis of housing supply factors above and the availability of data, the following variables are selected to build the model of urban housing supply in China. The data are derived from China Statistical Yearbook, China Real Estate Statistical Yearbook and National Bureau of Statistics of China website between 1998 and 2016.

Table 2 Variables of Supply Model of Urban Commercial Housing in China

\begin{tabular}{cccc}
\hline Variable Categories & Variable Description & Variable Names [unit] & Abbreviation \\
\hline \multirow{2}{*}{ Explained variable } & $\begin{array}{c}\text { Urban commercial } \\
\text { housing supply index }\end{array}$ & $\begin{array}{c}\text { Floor Area Completed of } \\
\text { Commercial Housing [10000 sq.m] }\end{array}$ & QS \\
\hline & $\begin{array}{c}\text { Urban commercial } \\
\text { housing price index } \\
\text { Economic development } \\
\text { level index }\end{array}$ & $\begin{array}{c}\text { Sold Price of Commercial Housing } \\
\text { [yuan/sq.m] }\end{array}$ & PT \\
& $\begin{array}{c}\text { Per Capita Gross Domestic Product } \\
\text { [yuan] }\end{array}$ & PCG \\
& $\begin{array}{c}\text { Housing fund investment } \\
\text { index }\end{array}$ & $\begin{array}{c}\text { Total Residence Investment } \\
\text { [100 million yuan] }\end{array}$ & RI \\
\hline
\end{tabular}

In order to eliminate the influence of data dimension and the possible heteroscedasticity of time series, the above indexes are processed by logarithm. After logarithmic processing, they are defined as LN_QS, LN_PT, LN_PCG and LN_RI. Then EViews7.2 is used to perform ADF test, co-integration test and Granger-causality test. Finally, the VAR model is constructed and the following equation is obtained:

LN_QS $=-1.2338 * \mathrm{D}\left(\mathrm{D}\left(\mathrm{LN} \_\mathrm{PCG}(-1)\right)\right)+0.1900 * \mathrm{D}\left(\mathrm{D}\left(\mathrm{LN} \_\mathrm{PCG}(-2)\right)\right)+0.5162 * \mathrm{D}\left(\mathrm{LN} \_\mathrm{PT}(-1)\right)+0.4$ $777 * \mathrm{D}\left(\mathrm{LN} \_\mathrm{PT}(-2)\right)+0.1018 * \mathrm{LN} \_\mathrm{QS}(-1)+0.7057 * \mathrm{LN} \_\mathrm{QS}(-2)+0.8985 * \mathrm{D}\left(\mathrm{D}\left(\mathrm{LN} \_\mathrm{RI}(-1)\right)\right)+0.4925 *$ D(D(LN_RI(-2)))+2.1616

\section{Prediction of Index}

Prediction of Urban Commercial Housing Price. Since the Housing Reform, sold price of urban commercial housing, which has the average annual growth rate of $7.83 \%$ (from 1,854 yuan/sq.m in 1998 to 7,205 yuan/sq.m in 2016), has been advancing by leaps and bounds. On the basis of the 
average growth rate of commercial housing from 1998, I have calculated the table below. It can be seen from table 3 that the average annual growth rate of China's sold price of commercial housing ranges from $7.6 \%$ to $11.3 \%$. With the background of China's New Normal and the trend of housing price since 1998, we can forecast the average price of commercial housing will slow down; however, because of the sticky housing price, price will continue to rise in a short period. Consequently, I predicate the growth rate of house price with three conditions: optimistic, neutral and pessimistic. The growth rate under different conditions is $6 \%, 4 \%$ and $2 \%$ respectively. The specific forecast values are shown in the following table 4.

\begin{tabular}{cc} 
Table 3 & \multicolumn{2}{c}{ Average Annual Growth Rate of Sold Price Calculated by Time Stage } \\
\hline Year & Average annual growth rate [\%] \\
\hline In the year of 2016 & 11.31 \\
Between 2011 and 2016 & 7.61 \\
Between 2006 and 2016 & 8.73 \\
Between 2001 and 2016 & 8.86 \\
Between 1998 and 2016 & 7.83 \\
\hline
\end{tabular}

Table 4 Sold Price of Commercial Housing under Different Conditions (2017-2020) [yuan/sq.m]

\begin{tabular}{ccccc}
\hline Condition & 2017E & 2018E & 2019E & 2020E \\
\hline Pessimistic & 7,349 & 7,496 & 7,646 & 7,799 \\
Neutral & 7,493 & 7,793 & 8,105 & 8,429 \\
Optimistic & 7,637 & 8,096 & 8,581 & 9,096 \\
\hline
\end{tabular}

Prediction of per Capita GDP, Urban Population and per Capita Disposable Income of Urban Residents. According to the prediction of the $13^{\text {th }}$ Five-Year Plan for Economic and Social Development of China, the average annual growth rate of GDP and per capita disposable income from 2016 to 2020 is at least $6.5 \%$. Besides, in the end of 2020, the population of China will be 1.42 billion, so the average annual growth rate is about $0.67 \%$ in the next four years. Mentioned in National Plan on New Urbanization (2014-2020), the ratio of urbanization will be $60 \%$ in 2020 , and the cumulative growth rate will be $3.9 \%$ during the $13^{\text {th }}$ Five-Year, while the average annual growth rate is about $0.66 \%$ over the next four years. The following table 5 provides some specific forecasted values.

Table 5 Forecast values of per Capita GDP, Urban Population and per Capita Disposable Income of Urban Residents (2015-2020)

\begin{tabular}{ccccccc}
\hline Year & $\begin{array}{c}\text { Total } \\
\text { Population } \\
{[10000} \\
\text { persons] }\end{array}$ & $\begin{array}{c}\text { Urban } \\
\text { Population } \\
{[10000} \\
\text { persons }]\end{array}$ & $\begin{array}{c}\text { Ratio of } \\
\text { Urbanization } \\
{[\%]}\end{array}$ & $\begin{array}{c}\text { Per Capita } \\
\text { Disposable } \\
\text { Income } \\
\text { [yuan] }\end{array}$ & $\begin{array}{c}\text { GDP } \\
{[100 \text { million }} \\
\text { yuan] }\end{array}$ & $\begin{array}{c}\text { Per GDP } \\
\text { [yuan] }\end{array}$ \\
\hline 2015 & 137,462 & 77,116 & 56.10 & $31,194.80$ & $685,505.80$ & 49,992 \\
2016 & 138,271 & 79,298 & 57.35 & $33,616.00$ & $744,127.00$ & 53,817 \\
$2017 \mathrm{E}$ & 139,194 & 80,750 & 58.01 & $35,801.04$ & $792,495.26$ & 56,935 \\
$2018 \mathrm{E}$ & 140,123 & 82,217 & 58.68 & $38,128.11$ & $844,007.45$ & 60,233 \\
$2019 \mathrm{E}$ & 141,058 & 83,701 & 59.34 & $40,606.43$ & $898,867.93$ & 63,723 \\
2020E & 142,000 & 85,200 & 60.00 & $43,245.85$ & $957,294.35$ & 67,415 \\
\hline AAGR & $0.67 \%$ & & $0.66 \%$ & $6.50 \%$ & $6.50 \%$ & \\
\hline Ren
\end{tabular}

Remarks: "AAGR" is the abbreviation of "the average annual growth rate". The data in the table above are calculated on the basis of the $13^{\text {th }}$ Five-Year planning target. Given formulas: (1) Urban Population=Total Population*Ratio of Urbanization; (2) Per GDP= GDP/ Total Population. 
Prediction of Total Residence Investment. According to the AAGR of total residence investment since 1998, I have calculated the table below. From table 6 we can see that the AAGR of total residence investment ranges from $6.4 \%$ to $21.4 \%$. A strong correlation between the growth rate of total residence investment and GDP developing is demonstrated in many papers. As mentioned above, the AAGR of GDP is over $6.5 \%$ during the $13^{\text {th }}$ Five-Year. Consequently, I still predicate the AAGR of residence investment with three conditions: optimistic, neutral and pessimistic, which is $7 \%, 4 \%$ and $1 \%$ respectively. The specific forecast values are shown in the following table 7.

Table 6 Average Annual Growth Rate of Residence Investment Calculated by Time Stages

\begin{tabular}{cc}
\hline Year & Average annual growth rate [\%] \\
\hline In the year of 2016 & 6.36 \\
Between 2011 and 2016 & 9.16 \\
Between 2006 and 2016 & 17.55 \\
Between 2001 and 2016 & 20.45 \\
Between 1998 and 2016 & 21.44 \\
\hline
\end{tabular}

Table 7 Total Residence Investment under Different Conditions (2017-2020) [100 million yuan]

\begin{tabular}{ccccc}
\hline Condition & 2017E & 2018E & 2019E & 2020E \\
\hline Pessimistic & $69,391.04$ & $70,084.95$ & $70,785.80$ & $71,493.66$ \\
Neutral & $71,452.16$ & $74,310.25$ & $77,282.66$ & $80,373.96$ \\
Optimistic & $73,513.28$ & $78,659.21$ & $84,165.35$ & $90,056.93$ \\
\hline
\end{tabular}

\section{Prediction of Total Supply and Demand for Urban Commercial Housing in China}

In the VAR model of total supply of urban commercial housing in China, there are three conditions of the prediction of housing sold price and residence investment, and the values of per GDP can be calculated by the final target of the $13^{\text {th }}$ Five-Year Plan. We bring the predicting numerical values into the VAR model of total supply of urban commercial housing, and the predicted values of floor area completed of commercial housing $\left(Q_{s}\right)$ can be also obtained (table 8). In the VAR model of total demand for urban commercial housing in China, except three conditions of prediction of housing sold price, the forecasted values of urban population and per capita disposable income can be calculated by the final target of the $13^{\text {th }}$ Five-Year Plan. We bring the predicting numerical values into the VAR model of total demand for urban commercial housing, and the predicted values of sold area of commercial housing $\left(Q_{d}\right)$ can be obtained (table 8 ).

Table 8 Predicted Values of Total Supply and Demand for Urban Commercial Housing in China (2017-2020) [10000 sq.m]

\begin{tabular}{ccrrr}
\hline Year & Square Index & \multicolumn{1}{c}{ Optimistic } & \multicolumn{1}{c}{ Neutral } & \multicolumn{1}{c}{ Pessimistic } \\
\hline \multirow{3}{*}{$2017 \mathrm{E}$} & $Q_{s}$ & $80,910.58$ & $80,910.58$ & $80,910.58$ \\
& $Q_{d}$ & $114,376.88$ & $114,376.88$ & $114,376.88$ \\
& $\Delta Q$ & $-33,466.30$ & $-33,466.30$ & $-33,466.30$ \\
\hline \multirow{3}{*}{$2018 \mathrm{E}$} & $Q_{s}$ & $88,705.58$ & $85,251.66$ & $82,567.32$ \\
& $Q_{d}$ & $155,991.71$ & $151,943.08$ & $147,923.97$ \\
& $\Delta Q$ & $-67,286.13$ & $-66,691.42$ & $-65,356.65$ \\
\hline \multirow{2}{*}{$2019 \mathrm{E}$} & $Q_{s}$ & $85,265.80$ & $81,975.40$ & $79,187.65$ \\
& $Q_{d}$ & $122,992.82$ & $119,501.92$ & $116,045.21$ \\
& $\Delta Q$ & $-37,727.02$ & $-37,526.52$ & $-36,857.56$ \\
\hline \multirow{2}{*}{$2020 \mathrm{E}$} & $Q_{s}$ & $90,650.46$ & $86,146.33$ & $82,322.87$ \\
& $Q_{d}$ & $169,307.92$ & $159,764.81$ & $150,589.86$ \\
& $\Delta Q$ & $-78,657.46$ & $-73,618.48$ & $-68,266.99$ \\
\hline
\end{tabular}




\section{Equilibrium Analysis on Total Supply and Demand for Urban Commercial Housing in China}

We draw the line chart by combining the actual values of sold area and floor area completed of urban commercial housing in China from 1998 to 2016 with the forecasted values of these indexes in the next four years. Finally, we get the following figure 3. From figure 3 we can find it is a normal that the supply and demand of urban commercial housing in China is imbalance since the housing reform. Before 2004, supply of urban commercial housing market exceeds its demand, but there is a small gap between housing supply and demand $\left(\Delta Q=Q_{d^{-}} Q_{s}\right)$; after 2004, housing market has remained tight, and $\Delta Q$ demonstrate a certain periodicity over time. In general, the gap between supply and demand has gradually widened.

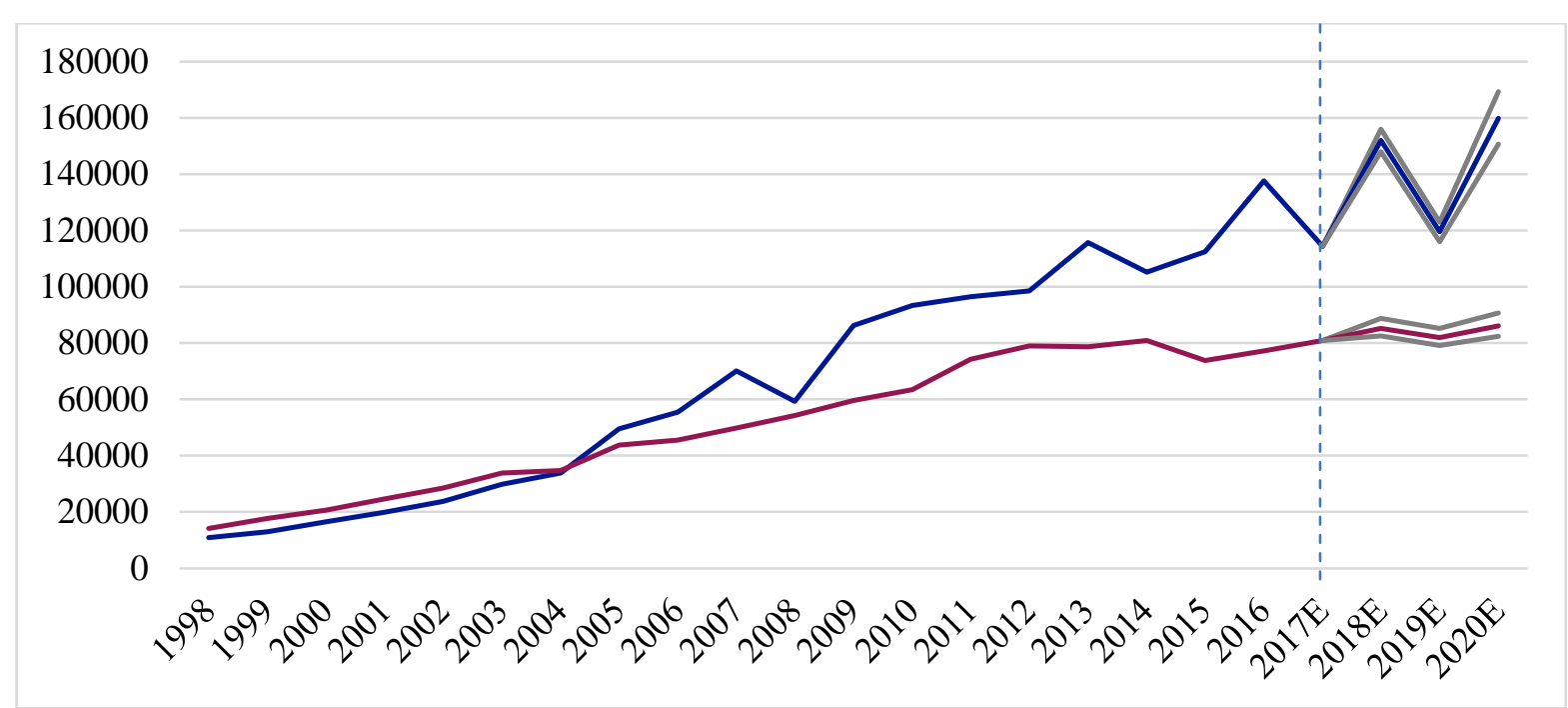

Fig. 3 Total Supply and Demand for Urban Commercial Housing in China (1998-2020)

Remarks: The curve from top to bottom is the housing demand for optimistic, neutral and pessimistic, and the housing supply for optimistic, neutral and pessimistic.

From the figure 3 we also can specifically see the supply and demand for urban commercial housing from 2017 to 2020 . Whether the growth rate is optimistic, neutral or pessimistic, China's urban housing market is still in short supply for the next four years, and supply-demand gap ranges from 335 million sq.m to 787 million sq.m. Meanwhile, it is more obvious about its imbalance phenomenon in 2020. As can be seen from the Figure 3, supply of urban commercial housing will remain steadily increasing in the next four years although a slight decline in 2019. It is a line graph which also describes the fluctuate tendency of housing demand. Following the hot market sales in 2016, housing market will be significantly under pressure in 2017 because of the regulation. With narrowing the gap between supply and demand, the year of 2017 will become a turning point. However, there exist some basic elements of the development of the housing market. With the acceleration of urbanization, new urban population will bring new housing demand; because of improving the standard of living, it will also generate a series of needs to improve and remove house, which will support the absolute sold scale remained at a high level in the next four years.

Overall, it is still an imbalance between supply and demand for the urban commercial housing in China. The demand for housing in first-tier cities and some second-tier cities has exceeded the supply. In lower-tier cities, housing market has been coming off demand and under the process of destocking. At present, government has not done the regulation and control on both supply and demand, and always focuses on short-term demand and long-term supply for managing housing market. With the background of housing market differentiation, government should combine supply and demand adjustment, combine short and long term regulation and deal with the relationship between the housing market and the development of China's New Normal. Only in this way can we promote the balanced development of urban commercial housing market in China. 


\section{Reference}

[1] J.M. Wang and T.M. Gao: China Soft Science, Vol. 160 (2004) No.4, p.69.

[2] Z.Z. Zou and L.L. Niu: Financial Research, Vol. 335 (2010) No.1, p.1.

[3] T. Yan: Research on Disequilibrium and Macro-regulation of Housing Market in Shanxi (MS., Shanxi University of Finance and Economics, China 2013), p.37.

[4] [C. Zhang: The influence of population structure on housing demand in China (Southwestern University of Finance and Economics Press, China 2015).

[5] G.H. Cao: Journal of Chongqing University (Natural Science Edition), Vol. 252 (2012) No.11, p.22.

[6] Z.Y. Ding: Research on Housing Market Development in the Process of Urbanization in China (Ph.D., East China Normal University, China 2013), p.56.

[7] D. Dipasquale and W.C. Wheaton: Urban Economics and Real Estate Markts (Economic Science Press, China 2002).

[8] D.Q. Jiang: Soft Science, Vol.66 (2001) No.6, p.37.

[9] H.Y. Liu and R.R. Ren: China Land Sciences, Vol.252 (2008) No.12, p.11.

[10] X.L. Tao: Urban Public Housing Policy Design on Supply and Demand Equilibrium Analysis (Social Sciences Academic Press, China 2012).

[11][] H.M. Zhang: Housing Economics (Shanghai University of Finance and Economics Press, China 1998).

[12][D.J. McKenzic and R.M. Betts: Basic Real Estate Appraisal (Renmin University of China, China 2009). 